\title{
Hospital in Indonesia: The Important Role of Career Success on Career Governance Systems for Staying in Organizations with Organizational Support Effects
}

\author{
Rudi Handoko \\ Student of Doctoral Economics, University of Merdeka Malang, Indonesia \\ Anwar Sanusi \\ Faculty of Economics and Business, University of Merdeka Malang, Indonesia \\ Harianto Respati (Corresponding author)* \\ Faculty of Economics and Business, University of Merdeka Malang, Indonesia \\ e-mail: patidarma@yahoo.com
}

\begin{abstract}
A hospital organization can run effectively if it is supported by the motives of nurses. The motive for the intention to remain a member of the organization becomes an important topic in the discussion of this journal. The purpose of this study was to find out the effect of organizational support, innovative behavior and self-esteem on the intention to continue working in the organization by considering the career success of nurses. The research was conducted in two major hospitals in Indonesia that have a good employee career system. The research design was quantitative. Research respondents were 130 nurses. Description and causal analysis to prove the hypothesis and test the effect between variables. Structural Equation Modeling analysis is used to explain the function of the intervening variable based on the simultaneous calculation of the coefficients in the analysis model. The findings of this study are that compensation in the form of bonuses and praise can not encourage nurses to intend to work in hospital organizations. Organizational support in the form of rewards in the form of a promising fixed salary and safe, comfortable, and conducive working conditions is precisely what nurses are looking for. The success of this organizational support has a strong impact on the intentions of nurses to continue working in hospital organizations.
\end{abstract}

Keywords: Organizational support, career success, intention to stay in the organization, hospital

DOI: $10.7176 / \mathrm{EJBM} / 13-23-01$

Publication date: December $31^{\text {st }} 2021$

\section{A. Introduction}

The employee's intention to remain in the organization/intention to stay is an employee's desire to continue working in the organization until the employee is forced to leave the organization for certain reasons (Ibrahim, 2016). An organization can run effectively if it is supported by human resources. The growth and development of an organization depend on the performance of its human resources. The employee's intention to remain a member of the organization determines the sustainability of the organization (Tepeci, 2001).

This research was conducted in a hospital that has a high number of organizational members, especially nurses. In addition, hospitals that have a clear career system are selected to measure career success variables. Nurses were chosen as research respondents because they are the front group and make a big contribution to hospital services. Hospitals must give rights and obligations to nurses to ensure their welfare. Welfare insurance creates a high intention to remain as a member of the organization and is reluctant to leave (Mobley et al. 1979).

This study was initiated by Tourangeu (2005) who has researched the Hospital Ontario Canada, there are four significant predictors of determining nurses to keep working in the organization, namely job satisfaction, personal characteristics of nurses, cohesion and teamwork. Tourangeu (2005) suggested that other factors influence the intention of nurses to stay in the organization so that they are studied more deeply related to the sustainability of organizational performance.

Liu (2015) conducted a study at the Tianjin Hospital in China, the results of the study prove that organizational support is related to career success, male nurses are more confident. Career success mediates self-esteem intending to stay with the organization. Dan et al. (2017) conducted a study on nurses in China's Tianjin hospital, the results illustrate that the level of career success still needs to be improved.

Nurses' low intention to stay in the organization has long been discussed and has become a global issue in the world (Currie, 2012). Nurses' low intention to stay has become a serious problem for hospitals because it causes instability in labor conditions and increases in human resources such as training and recruitment costs (Waldman et al, 2004). Elatybani (2018) conducted a study at the Tokyo Hospital, the results stated that high support from nurse managers can help nurses to work longer in hospitals. 
Based on the results of research and recommendations from previous researchers, is it true that career success is an important part for hospital organizations such as the support of nurses to predict the level of the intention of nurses to continue working in the organization? In addition, what is the role of career success in addressing organizational support to predict nurses' intentions to continue working in hospital organizations? Various research results explain that a bad career system causes high labor turnover. The results of this study are useful for organizations that implement a career governance system, for decision-making in the field of human resources.

\section{B. Literature Review.}

1. Intention to remain in the organization

The intention to remain in the organization is an individual thought to stay and work in the organization (Liu, 2015). The intention of employees to remain in the organization is a condition where employees tend to want to stay with the organization until circumstances force them to leave or leave the organization (Ibrahim, 2016). Intention to remain in the organization is the intention of nurses to continue working as a nursing profession to keep working in the organization (Gizaw, 2017). Effective commitment and loyalty are a reflection of organizational individuals to intend to stay and work in the organization and have no intention to leave the organization (Liu, 2015).

2. Career success.

A career is formally defined as the satisfaction that a person achieves in his professional life as an accumulation of the results of a person's various work experiences (Judge et al, 2008). Career success is a positive psychological condition or result of work or personal achievement and professional achievement obtained from their work experience (Seibert et al., 2001, Breland et al., 2007). Career success is part of employee behavior. The compensation received and the acquisition of positions in the organization is a reflection of career success (Judge et al., 1995)

3. Organizational support.

Organizational support is part of the organization's commitment to employees in carrying out their functions, roles, and responsibilities. The form of the organization in providing support such as an appreciation for the dedication, guarantee of a decent life, and justice (Eisenberger et al, 2002). According to Fuller et al. (2006), organizational support is an employee assessment to find out a condition and the organization's concern for employees. Organizational support is part of the organization's responsibility to meet all the needs and desires of members based on an assessment of the organization's capabilities.

\section{Conceptual framework}

This study describes the effect of organizational support on intentions to remain in the organization and is intervened by career success. Organizational support for the function and role of resources is an important part of the organization. Building a fair climate, superior support for employees, providing rewards, and creating conducive working conditions (Eisenberger et al., 2002) can directly impact employees' intentions to remain in the organization (Armstrong, 2009; Arasanmi, 2019).

The function and role of the organization in providing support to employees so that they have the resilience to remain members of the organization will be better if there is a career guarantee (Dan et al, 2017; Chen, 2010; Liu, 2015). This means that career success is an important part of employees. Therefore, the organization seeks to build a conducive career system and good governance. The description above can be hypothesized:

H1. There is an influence of organizational support on Intention to remain in the organization

$\mathrm{H} 2$. There is an influence of organizational support on career success

$\mathrm{H} 3$. There is an influence of career success on the intention to remain in the organization

H4. Career success mediates organizational support for the intention to remain in the organization. 
Figure 1. Research structural equation model

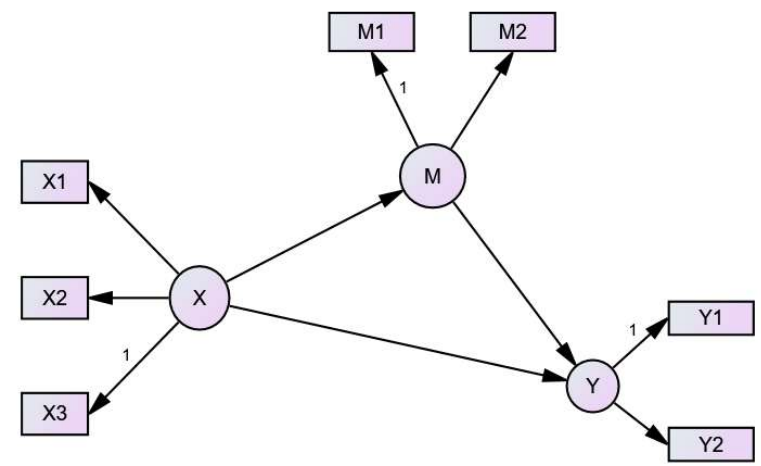

Note:

\begin{tabular}{|c|l|l|l|}
\hline Variable & $\mathrm{X}$ - organizational support & $\mathrm{M}$ - career success & Y- Intention to remain in the organization \\
\hline Indicator 1 & $\mathrm{X} 1$ - Justice & $\mathrm{M} 1$ - Compensation & Y1 - Effective commitment \\
\hline Indicator 2 & $\mathrm{X} 2$ - Superior support & $\begin{array}{c}\mathrm{M} 2-\text { Managerial } \\
\text { Department }\end{array}$ & $\mathrm{Y} 2$ - Faithfulness \\
\hline Indicator 3 & $\mathrm{X} 3$ - Rewards & & \\
\hline
\end{tabular}

\section{Research method}

1. Design and sample

The design of this study is a quantitative causality study, which is to analyzes the relationship between exogenous and endogenous variables. To explain the description of the variables studied using descriptive analysis. This research also includes explanatory research, namely research that emphasizes the causal relationship between exogenous variables $(\mathrm{X})$, endogenous variables (Y), and mediation $(\mathrm{M})$. The sample of this study were nurses in two well-known hospitals in Indonesia, East Java, Malang City.

Two hospitals in Indonesia were chosen as research locations because they have a good career management system. Selected as many as 130 respondents by referring to the solving formula (error rate is 7\%) from a population of 1013 nurses. The questionnaire instrument was used to collect primary data. The questionnaire consists of 14 statement items, five options are provided to answer the statement items. The Likert scale was chosen to describe the tendency of respondents' perceptions with the choice of strongly agree (score 5), neutral (score 3), to strongly disagree (score 1). Questionnaires were distributed through google form and questionnaire sheets. Researchers assist respondents in answering the questionnaire items.

2. Data Analysis Techniques.

This study wants to explain the description of research variables and the influence between variables, especially the explanation of the role of the mediating/intervening variable. The data analysis technique used descriptive analysis and structural equation modeling. Respondents' answers were tabulated and statistical processes were carried out assisted by the SPSS and AMOS programs.

\section{E. Research results}

\section{Respondent profile}

The majority of women 118 (69\%), men 52 (30.4\%), majority age 26-30 years 45 people (26.4\%), education level majority Diploma in Nursing $110(64,7 \%)$, the majority are married $129(75.9 \%)$, the majority position is operational nurse $93(54.4 \%)$, the majority working period is $1-5$ years $72(42.1 \%)$

2. Description of research variables.

The data collected were tabulated in the SPSSS program and instrument testing was performed. The results of the instrument test show that the 14 statement items have a good level of validity and a good level of reliability accuracy as well. Mode analysis is used by the researcher to describe the respondent's perception.

Organizational support, mostly $103(60.2 \%)$ respondents answered that the majority agreed that hospital management distributed nurses according to room needs. $119(70 \%)$ majority of respondents agree that the hospital in making decisions/policies supports employees. The majority of $109(64.1 \%)$ respondents agreed that the leadership had made plans, carried out plans, and carried out evaluations. 120 (74.5\%) majority of respondents agree that the leadership provides support to employees to improve services. 130 (76.4\%) majority of respondents agree that the salary given by the hospital is above the minimum wage following competence. $131(77.1 \%)$ majority of respondents agree that hospital management has given rewards for employees who perform well and provides punishment for employees who violate the rules. 
Career success there are $149(87.6 \%)$ respondents, the majority agree that I have received a bonus/service fee other than salary. $130(76.4 \%)$ majority respondents agree that praise from superiors for work performance increases. $118(69.5 \%)$ majority of respondents agree that the promotion is because I excel. $122(71.8 \%)$ majority of respondents agreed that I was a team leader, head of the room, coordinator of nursing services, head of the section, head of nursing.

Intention to remain in the organization $160(94.1 \%)$ majority agreed that they still want to work at this hospital. 147 (86.5\%) majority respondents agree that they work according to their competence to achieve organizational goals. $136(80 \%)$ majority of respondents agree that complying and supporting hospital management is improving services. $142(83.5 \%)$ majority of respondents agree that they are willing to continue working at this hospital until retirement even though there are better job offers.

3. Analysis Results Assumptions of structural equation model

The low number of critical ratio skewness is -2.191 and the highest number of critical ratio skewness is 0.503. The lowest $(-2.191)$ and highest (0.503) values are still in the range of -2.58 and 2.58 . So that the research data collected is normally distributed.

The results of the analysis show that none of the d-squared Mahalanobis values exceed the Chi-Square table value $(\alpha=0.001 ; \mathrm{df}=44$ of 31.26$)$. It can be concluded that there are no outliers in the observation data. The result of heteroscedasticity analysis is to test the relationship between exogenous and endogenous variable indicators. Seven indicators were tested for correlation. The results of the correlation matrix show that no correlation number exceeds 0.9 . From the results of this correlation, it can be concluded that in the structural equation model built there is no multicollinearity problem between the indicators studied.

4. Structural equation model analysis results

There is one exogenous latent variable with three indicators, one mediating variable with two indicators, and one indigenous latent variable with two indicators. The results of the analysis of the structural equation model using the AMOS program produced coefficients and loading figures as shown in Figure 2.

Figure 2. Coefficient and factor loading of structural equation model

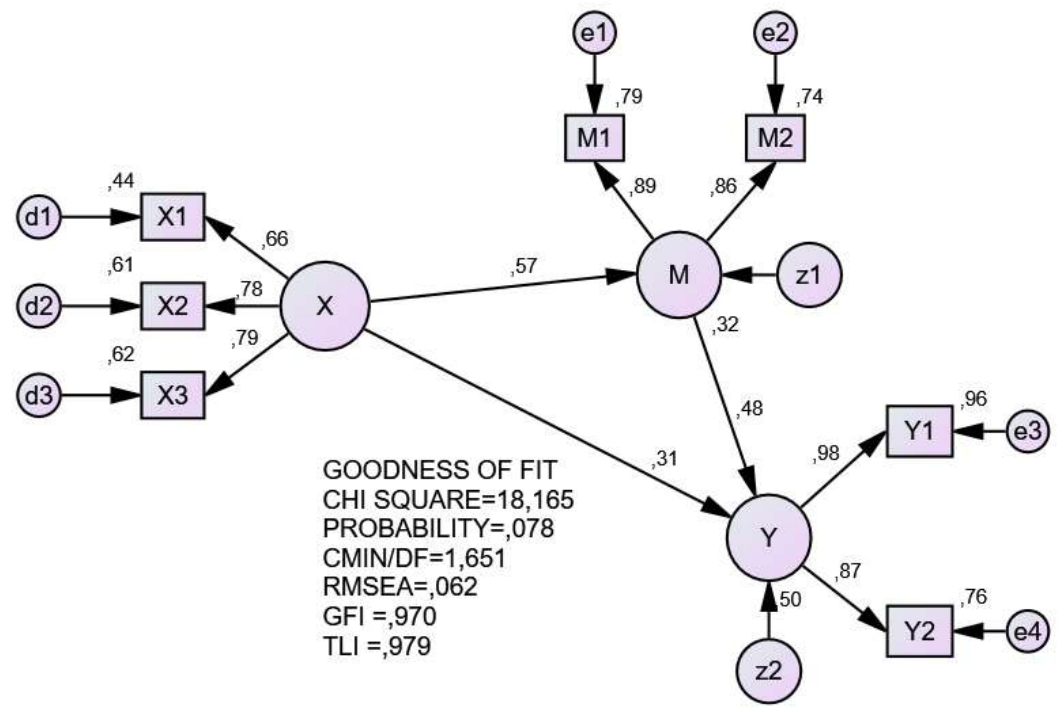

The results of the evaluation of the structural equation model show that the calculated Chi-Square value is 18.165 compared to the Chi-Square table $(\alpha=0.001 ; \mathrm{df}=11$ is 19.675$)$. The results of this comparison show that Ho's criteria are accepted, meaning that the structural equation model built based on the theory can explain the phenomenon measured by the researcher. In addition, the probability level generated by the SEM model is nonsig. (0.078) with a tolerance level of CMIN/DF $=1.651<2.00$; RMSEA $=0.062<0.08$; GFI $=0.970>0.90$ and $\mathrm{TLI}=0.797>0.95$. This comparison resulted in the same conclusion that the model was accepted. The results of the path analysis and research hypotheses are presented in Table 1 below. 
Table 1. Results of path analysis and hypothesis testing

\begin{tabular}{|c|c|c|c|c|c|c|c|}
\hline \multicolumn{3}{|c|}{ Variables } & \multicolumn{3}{|c|}{ Path } & \multirow[t]{2}{*}{ p. } & \multirow{2}{*}{$\begin{array}{l}\text { Hypothesis } \\
\text { result }\end{array}$} \\
\hline indigenous & mediation & exogenous & direct & indirect & total & & \\
\hline $\begin{array}{l}\text { Organizational } \\
\text { support }\end{array}$ & - & $\begin{array}{l}\text { Intention to remain in } \\
\text { the organization }\end{array}$ & 0,31 & - & 0,31 & 0,000 & $\begin{array}{l}\text { H1 } \\
\text { Acepted }\end{array}$ \\
\hline $\begin{array}{l}\text { Organizational } \\
\text { support }\end{array}$ & $\begin{array}{l}\text { career } \\
\text { success }\end{array}$ & - & 0,57 & - & 0,57 & 0,000 & $\begin{array}{l}\mathrm{H} 2 \\
\text { Acepted }\end{array}$ \\
\hline- & $\begin{array}{l}\text { career } \\
\text { success }\end{array}$ & $\begin{array}{l}\text { Intention to remain in } \\
\text { the organization }\end{array}$ & 0,48 & - & 0,48 & 0,000 & $\begin{array}{l}\text { H3 } \\
\text { Acepted }\end{array}$ \\
\hline $\begin{array}{l}\text { Organizational } \\
\text { support }\end{array}$ & $\begin{array}{l}\text { career } \\
\text { success }\end{array}$ & $\begin{array}{l}\text { Intention to remain in } \\
\text { the organization }\end{array}$ & 0,31 & $0,27 *$ & $0,58 *$ & Sig. & $\begin{array}{l}\mathrm{H} 4 \\
\text { Acepted }\end{array}$ \\
\hline
\end{tabular}

Note: *) indicates p. less than 0.05

The results showed that organizational support had a significant effect on career success and intention to remain in the organization. And career success has a significant effect on the intention to remain in the organization. Career success can mediate the effect of organizational support on intentions to remain in the organization. The results of the observation of the direct path of 0.31 have more effect than the indirect path of 0.27 ; this shows that the role of the mediating variable (career success) is not optimal enough as a mediator.

\section{F. Discussion}

Hospital organizational support is measured by three indicators, namely (1) fairness, (2) superior support, (3) remuneration. The results of the factor loading test show that rewards can better reflect organizational support in hospitals, especially in awarding nurses who excel and punishing those who violate. The rewards that nurses receive according to their perception are adequate

Intention to remain in the organization is measured by two indicators, namely effective commitment, and loyalty. The results of the analysis show that effective commitment is better able to reflect the intentions of nurses to continue working in the organization. Nurses assume that they intend to work together to achieve organizational goals following their competencies.

Career success is measured by two indicators, namely compensation and managerial positions. The success of the nursing workforce appears when they feel they receive more compensation and gain confidence to occupy certain positions. Compensation is more reflective of career success in the view of nurses who work in hospital organizations. According to respondents' perceptions, the most prominent compensation is getting a bonus/service fee in addition to salary followed by getting praise from superiors because of increased work performance.

Hospital organizations prioritize rewards and create conducive working conditions in providing support to employees, especially nurses. The nurses feel that they are happy with the rewards they receive and they also feel that the working conditions are conducive. The impact of organizational support is to reward employees who excel and provide punishment for employees who violate the rules. Salaries above the wages received are proven to encourage careers and intentions to continue working in hospital organizations.

Nurses feel that compensation in the form of getting a bonus/service fee in addition to salary is followed by getting praise from superiors because work performance increases. The impact of getting a bonus/service fee other than salary is followed by getting praise from superiors because work performance increases. Impact on the nurse's intention to remain in the organization. This is evidenced by their affective commitment. Nurses are committed to achieving organizational goals effectively according to their abilities.

Nurses' career success can be felt from the compensation they receive. The results of the path analysis prove that compensation in the form of bonuses and praise can not encourage nurses to intend to work in hospital organizations. It is precisely the organizational support in the form of rewards in the form of a promising fixed salary and safe, comfortable, and conducive working conditions that nurses are looking for. The success of this organizational support has a strong impact on the intentions of nurses to continue working in hospital organizations.

\section{G. Conclusions and recommendations}

In hospital organizations that have implemented a good career system, there are still obstacles that compensation in the form of bonuses that are not effective enough to create an intention to continue working in hospital organizations.

The career system is a system that regulates the career journey of hospital employees, but giving bonuses and others is a management policy. This means that hospital management policies in the form of bonuses and the provision of money instead of other services have proven to be ineffective in encouraging the intention to remain in the organization. Promising remuneration and conducive working conditions are the best choices, especially for nurses. This research has proven that there is a strong influence of organizational support on intentions to remain in the organization. 
Hospitals must be committed to paying attention to and ensuring the welfare of nurses so that nurses do not leave and move to other places. Several things can be done by the hospital board of directors such as providing support, facilitating innovation, increasing nurses' self-esteem, and paying attention to nurses' career paths (Dan, 2018; Liu, 2015). Innovative behavior and employee self-esteem become an important part of the factors that influence career success and intention to remain in the organization which can be tested for future researchers.

\section{References}

Arasanmi, 2019. Employer branding: perceived organizational support and employee retention the mediating role of organizational commitment. International journal of Industrial and Commercial Training. Vol.51 No.3

Armstrong, M., and Taylor, S. 2014. Armstrong's Handbook of Human Resources Management Practice. The United Kingdom. Kogan Page.

Armstrong. 2009. Perceived Organizational Support, Career Satisfaction, and The Retention of Older Workers. International Journal of Occupational and Organizational Psychological Society Vol. 82, No.1 pp.201220.

Breland, J. W., Treadway, D.C., Duke, A.B., and Adams, G.L. 2007. The Interactive Effect of leader Member Exchange and Political Skill on Subjective career Success. Journal of leadership and Organizational Studies. Vol 13. No.3. pp. 1-14.

Chen, Yu. 2010. Career Success of Knowledge Workers: The Effect of Perceived Organizational Support and Person Job Fit. Business 2, 389-394. Commitment, and Innovation. Journal of Applied Psychology. Vol.2 No.4

Currie, E.J. 2012. What Are The Reasons For Hight Turnover in Nursing? A Discussion Of Presumed Causal Factors and Remedies. International Journal Of Nursing Studies. Vol. 49, No.9 pp 1180-1189.

Dan, Xi., Xu, Suhuan., Liu, Jingying., Hou, Ruonan., and Ma, Hongwen. 2017. Innovative Behavior and Career Success: Mediating Roles of Self Efficacy and Colleague Solidarity of Nurses. International Journal of Nursing Science, Vol.8 No.4 275-280.

Eisenberger. 1986. Perceived Organizational Support and Employee Diligence, Commitment, and Innovation. Journal of Applied Psychology Vol. 75 No.1, 51-59.

Eisenberger, Stinglhamber and Vandenberghe 2002. Perceived supervisor support: Contributions to perceived organizational support and employee retention. Journal of Applied Psychology Vol. 87 No. 3, pp. 563-573

Eltaybani. 2018. Factors Related to Intention to Stay In The Current Workplace Among Long term care Nurses Vol.80

Fuller, J.B., Marier, L. E., Hester, K. 2006. Promoting Felt Responsible For Constructive Change and Proactive Behavior: Exploration aspect of an Elaborated model of work design. Journal of Organizational Behavior, Vol. 27, No. 8 pp.1089-1120.

Gizaw. 2017. Intention to Stay in Nursing Profession and Its Predictors among Nurses Working in Jimma Zone Public Hospitals, South West Ethiopia. Journal of Nursing and Care. Vol.7 Issue 1, 1000440.

Ibrahim. 2016. Budaya etika, Niat untuk bertahan dalam organisasi dan kesesuaian dengan organisasi sebagai mediator. Jurnal Ekonomi Manajemen dan Akuntansi. Vol.2 No.1

Judge, T. A., Cable, D. M., Boudreau, J. W., and Bretz, R. D. 1995. An Empirical Investigation of The Predictors of Executive Career Success. Personnel Psychology. Vol.48 No.3: 485-519.

Judge, A Timothy., Kammeyer, J., and Bretz, D, Robert. 2004. A Longitudinal Model of Sponsorship and Career Success: a Study of Industrial-Organizational Psychologist. Personnel Psychology, Vol..57 No.2: 271-303.

Judge, T. A., and Hurst, C. 2008. How The Rich (and Happy) Get Richer (and Happier): Relationship of Core Self Evaluations to Trajectories in Attaining Work Success. Journal of Applied Psychology, 93(4), 849-863. Vol.93 No.4

Liu, Jing Ying 2015. The Relationships Among Perceived Organizational Support, Intention to Remain, Career Success and Self Esteem In Chinese male Nurses. International Journal of Nursing Sciences 2, 389-393. Vol.2 No.4

Mobley. 1979. Review and Conceptual Analysis of the Employee Turnover process. Psychological Bulletin, 86:493-522 Books

Person Organization Fit on Individual Outcomes in Restaurant Industry. A Thesis in Man Environment relations. The Pennsylvania State University. The graduate school of hotel, Restaurant, and Recreation management

Seibert, S., Kraimer, M., and Liden,R. 2001. A social Capital Theory of Career Success. Academy of Management Journal, Vol.44 No 2

Scot, S. G., and Bruce. 1994. Determinants of innovative behavior: A Path Model of individual innovation in the workplace. Academy of Management Journal Vol. 37. No.3, 580-607.

Tepeci, Mustapha. 2001. The Effect of Personal values, Organizational Culture, and person Organization Fit On Individual Outcomes In The Restaurant Industry Vol.62 No.6-A

Tourangeau. 2005. Nurse Intention to Remain Employed: Understanding and Strengthening Determinants. 
Journal of Advanced Nursing 55 (4), 497-509. Vol 55. No.4

Waldman, J.D., Kelly, F., Arora, S. and Smith, H. L. 2004. Shocking Cost of Turnover in Health Care. Management Review, 29, pp.2-7 Vol.35. No 3 